\title{
Kebijakan Hutang, Ukuran Perusahaan dan Kinerja Keuangan Terhadap Nilai Perusahaan: Industri Perbankan di Indonesia
}

\author{
Sugeng Haryanto, Nabila Rahadian, Maria Fatima Ima Mbapa, \\ Eka Nesty Rahayu dan Khoiriyah Vivi Febriyanti
}

Program D3 Keuangan dan Perbankan Universitas Merdeka Malang

J1. Terusan Raya Dieng No. 57, Malang, 65146, Indonesia

\section{Info Article}

History Article:

Approved: 8 December 2018

Published: 25 December 2018

Keywords:

Debt to equity ratio; Firm size; Profitability; Price earning ratio

ISSN (print) : 2598-7763

ISSN (online): 2598-7771

$\triangle$ Corresponding Author: Sugeng Haryanto Tel. / Fax. +81332373081 E-mail:p3et@yahoo.com

\begin{abstract}
Abtract
This study aims to analyze the influence of debt policy, firm size and financial performance on firm value. Debt policy is measured by a debt to equity ratio (DER). Financial performance is proxied by company profitability, namely return on assets (ROA) and company value proxied by Price earnings ratio (PER). The population in this study is a banking company that goes public on the Indonesia Stock Exchange. The sampling technique was used with purposive sampling. The observation period was conducted in 2013-2016, with a total sample of 27 banks. The amount of observation data is 108 pairs of data. Data analysis techniques used multiple linear regression. The results of the study show that the capital structure policy influences the value of the company in a negative direction. Company size does not affect company value. Company performance affects the value of the company in a positive direction.
\end{abstract}

Citation: Haryanto, Sugeng, Rahadian, N., Mbapa, M.F.I., Rahayu, E.N. dan Febriyanto, K.V. (2018). Kebijakan Hutang, Ukuran Perusahaan dan Kinerja Keuangan Terhadap Nilai Perusahaan: Industri Perbankan di Indonesia. Accounting and Financial Review, 1 (2)

\begin{abstract}
Abstraks
Penelitian ini bertujuan untuk menganalisis pengaruh kebijakan hutang, ukuran perusahaan dan kinerja keuangan terhadap nilai perusahaan. Kebijakan hutang diukur dengan rasio hutang terhadap modal (DER). Kinerja keuangan diproksi dengan profitabilitas perusahaan, yaitu return on asset (ROA) dan nilai perusahaan diproksi dengan Price earning ratio (PER). Populasi dalam penelitian ini adalah perusahaan perbankan yang go public di Bursa Efek Indonesia. Teknik pengambilan sampel digunakan dengan purposive sampling. Periode pengamatan dilakukan pada 2013-2016, dengan total sampel 27 bank. Jumlah data observasi adalah 108 pasang data. Teknik analisis data menggunakan regresi linier berganda. Hasil penelitian menunjukkan bahwa kebijakan struktur modal berpengaruh terhadap nilai perusahaan dengan arah negatif. Ukuran perusahaan tidak berpengaruh terhadap nilai perusahaan. Kinerja perusahaan berpengaruh nilai perusahaan dengan arah positif
\end{abstract}

JEL Classification G31, G32

DOI: https://doi.org/10.26905/afr.v1i2.2279

\section{PENDAHULUAN}

Prospek sutu perusahaan dapat dilihat dari bagaimana kinerja keuangannya. Kinerja keuangan perusahaan merupakan salah satu informasi yang menjadi pertimbangan pengambilan keputusan investor. Investor akan menginvetasikan dananya pada perusahaan-perusahaan yang memiliki kinerja keuangan yang baik. Perusahaan dengan kinerja yang baik, cenderung memiliki risiko yang rendah.

Profitabilitas merupakan cerminan kinerja keuangan perusahaan. Profitabilitas perusahaan yang tinggi menunjukkan kinerja perusahaan semakin baik. Investor sangat berkepentingan de- 
ngan informasi kinerja keuangan perusahaan. Keputusan investor yang tercermin dari harga saham akan sangat dipengaruhi oleh profitabilitas. Perusahaan dengan profitabilitas yang yang tinggi menunjukkan manajamen mampu melakukan efisiensi dalam perputaran asset perusahaan. Profitabilitas yang tinggi akan cenderung direspon positif investor, sehingga nilai perusahaan akan cenderung meningkat.

Salah satu tujuan perusahaan adalah bagaimana nilai perusahaan meningkat. Semakin tinggi nilai perusahaan menunjukkan kesejahteraan pemilik yang meningkat.

Hasil riset Hidayah (2014) menunjukkan bahwa nilai perusahaan yang tinggi akan meningkatkan kepercayaan investor untuk berinvestasi di perusahaan. Manajemen sebagai agen, akan mengelola aset perusahaan dan mengambil berbagai kebijakan dalam upaya meningkatkan kinerja perusahaan. Kebijakan perusahaan, terutama terkait dengan manajemen keuangan akan terkait dan berimplikasi pada keuangan perusahaan.

Hutang merupakan alternatif sumber dana perusahaan. Proporsi hutang perusahaan sebagai sumber pendanaan tercermin dari struktur modal perusahaan. Manajemen akan berusaha mencari struktur modal yang optimal. Sumber dana hutang akan menimbulkan biaya, namun di sisi lain diharapkan dari hutang akan mampu menjadi pengungkit pertumbuhan perusahaan. Sehingga profitabilitas perusahaan akan meningkat.

Dalam agency theory keberadaan hutang akan mampu menekan terjadinya konflik antara agency dan principal, yang dikenal dengan agency problem. Agency problem dapat dikurangi dengan keberadaan hutang (Chandrarin dan Sukanti, 2018). Penggunaan hutang membuat pengawasan terhadap manajemen tidak hanya dilakukan oleh para pemegang saham, namun juga oleh kreditur. Perilaku manajemen yang opportunistik, dapat ditekan dengan keberadaan hutang (Yulianto, 2013).

Investor berkeyakinan bahwa perusahaan yang mengambil hutang sebagai sumber pembiayaan yakin perusahaan tersebut akan mampu mengembalikan di masa yang akan datang. Perusahaan akan memiliki prospek yang lebih baik. Dalam jangka pendek, ketika hutang perusahaan yang digunakan untuk investasi, maka beban akan lebih besar dibandingkan dengan tingkat pengembalian dari tersebut. Profitabilitas perusahaan akan cenderung tertekan, namun jangka panjang seiring dengan investasi dari hutang tersebut telah produktif, maka profitabilitas akan cenderung meningkat. Dalam jangka pendek biaya hutang akan lebih tinggi, sehingga nilai perusahaan akan cenderung meningkat. Namun, dengan semakin besar hutang, risiko perusahaan akan semakin tinggi. Andrade \& Kaplan (1998); Zichao, Lu dan Ruiyang, Xu (2018) perusahaan dengan hutang yang tinggi cenderung akan memiliki risiko keuangan yang tinggi, seperti kesulitan keuangan dan risiko kebangkrutan. Menurut penelitian Vavatu (2015) yang melakukan penelitian di perusahaan Romania menunjukkan bahwa kinerja perusahaan akan cenderung lebih baik, ketika perusahaan menghindari penggunaan hutang.

Hasil riset menunjukkan bahwa proporsi hutang sampai pada tingkat tertentu akan berdampak positif terhadap nilai perusahaan, namun setelah proporsi tertentu hutang justur berdampak negatif. Temuan penelitian Cuong dan Canh (2012) menunjukkan bahwa ketika rasio utang kurang dari $59,27 \%$, maka hutang dapat meningkatkan nilai perusahaan. Namun ketika rasio hutang di atas $59,27 \%$, maka peningkatan hutang cenderung berdampak negatif terhadap nilai perusahaan. Hal ini mengisyaratkan bahwa ketika proporsi hutang perusahaan semakin besar, maka beban dan risiko perusahaan akan semakin tinggi. Hermuningsih (2013), Haryanto (2014) Struktur modal berpengaruh terhadap nilai perusahaan. Hutang jangka panjang berpengaruh positif terhadap nilai perusahaan (Ogbulu dan Emeni (2012). Selanjutnya, Detthamrong, Chancharat dan Vithessonthi (2017) leverage perusahaan berpengaruh pada kinerja perusahaan. Temuan Vo \& Ellis (2017) menunjukkan struktur modal berhubungan negatif dengan kinerja perusahaan. Sedangkan Petta dan Tarigan (2017) menemukan peningkatan hutang cendrung akan menurunkan kinerja keuangan perusahaan. Dimana manfaat hutang dari penghematan pajak mungkin lebih kecil daripada biaya kesulitan keuangan. Chowdhury dan Chowdhury (2010); Artini dan Puspaningsih (2011); Kodongo, Mokoteli dan Maina (2014), Sulistiono (2016) menunjukkan struktur modal tidak berpengaruh terhadap nilai perusahaan. Selanjutnya Chadha and Sharma (2015) menunjukkan bahwa leverage tidak berdam-pak pada kinerja perusahaan. Subagyo (2011) menemukan bahwa efektifitas hutang terhadap nilai perusahaan dipengaruhi oleh peluang investasi.

Perusahaan dengan aset yang semakin besar cenderung akan memiliki pangsa pasar yang semakin besar. Perusahaan yang sudah establish cenderung merupakan perusahaan besar. Perusahaan tersebut telah mampu bertahan dalam dalam lingkungan bisnis yang berubah-ubah. Risiko perusahaan dengan aset yang besar cenderung akan 
Kebijakan Hutang, Ukuran Perusahaan dan Kinerja Keuangan Terhadap Nilai Perusahaan: Industri Perbankan di Indonesia

Sugeng Haryanto, Nabila Rahadian, Maria Fatima Ima Mbapa, Eka Nesty Rahayu, dan Khoiriyah Vivi Febriyanti,

lebih rendah, dibandingkan dengan perusahaan kecil. Perusahaan dengan aset yang besar cenderung akan mampu menguasai market share yang besar. Kinerja perusahaan besar lebih menjanjikan dibandingkan dengan perusahaan kecil (Lin, 2006; Wright dan Ferris, 1997 dan Calisir et al., 2010). Namun, semakin besar perusahaan, maka kemampuan untuk melakukan perubahan tidak dapat dilakukan dengan cepat. Perusahaan besar seringkali dihadapkan pada masalah kecepatan untuk melakukan perubahan. Lingkungan bisnis yang cenderung cepat berubah atau turbulance, kecepatan perusahaan melakukan adaptasi penting. Kemampuan perubahaan besar terkadang lambat melakukan adaptasi terhadap perubahan lingkungan bisnis. Perusahaan kecil (ramping) cenderung lebih cepat berubah dibandingkan dengan perusahaan besar. Hasil penelitian Siregar, Roekhudin dan Purwanti (2018) menunjukkan bahwa ukuran perusahaan berpengaruh negatif terhadap nilai perusahaan. Sedangkan Hasnawati1 dan Sawir (2015) yang melakukan penelitian pada tiga kondisi ekonomi, yaitu masa sebelum krisis, periode krisi dan setelah krisis ukran perusahaan merupakan faktor yang penting menjadi pertimbangan investor. Temuan penelitian Suteja dan Ginting (2014) menunjukkan bahwa total asset perusahaan berdampak positif terhadap profitabilitas perusahaan.

Tujuan penelitian in adalah sebagai berikut: 1) untuk menganalisis pengaruh kebijakan hutang, ukuran perusahaan dan kinerja perusahaan terhadap nilaiperusahaan, 2) untuk mengatahui pengaruh kebijakan hutang, ukuran perusahaan dan kinerja perusahaan secara simultan terhadap nilaiperusahaan dan 3) untuk mengetahui variabel yang mempunyai pengaruh dominan terhadap nilai perusahaan.

\section{PENGEMBANGAN HIPOTESIS}

\section{Kebijakan Hutang dan Nilai Perusahaan}

Dalam pecking order theory (Myers dan Majluf, 1984) manajemen dalam membiayai perusahaan dari laba di tahan, jika tidak mencukupi baru menggunakan hutang, kemudian baru dari ekuitas. Dalam teori struktur modal, manajemen akan berusaha mencari struktur modal yang optimal. Besar kecilnya proporsi hutang sebagi sumber dana dilakukan dengan mempertimbangkan benefit and cost yang berhungan dengan leverage. Struktur modal yang optimal akan dapat meningkatkan nilai perusahaan. Manajemen dalam menentukan struktur modal yang optimal akan memperhatikan antara tingkat pengembalian hutang, penghematan pajak, dengan agency cost, dan financial distress (Jensen dan Meckling, 1976).

Hasil penelitian Cuong dan Canh (2012) menunjukkan bahwa struktur modal pada proporsi tertentu akan berdampak positif pada nilai perusahaan. Namun, jika proporsi hutang sudah sangat besar, justru akan berdampak negatif terhadap nilai perusahaan. Antwi, Mills dan Zhao (2012), Ogbolu dan Emeni (2012) menemukan bahwa di negara yang berkembang hutang jangka panjang berpengaruh terhadap nilai perusahaan.

$\mathrm{H}_{1}$ : Struktur modal berpengaruh terhadap nilai perusahaan.

\section{Ukuran Perusahaan dan Nilai Perusahaan}

Salah satu tolok ukur yang menunjukkan besar kecilnya perusahaan adalah ukuran aktiva dari perusahaan tersebut. Perusahaan yang memiliki total aktiva besar menunjukkan bahwa perusahaan tersebut telah mencapai tahap kedewasaan dimana dalam tahap ini arus kas perusahaan sudah positif dan dianggap memiliki prospek yang baik dalam jangka waktu yang relatif lama, selain itu juga mencerminkan bahwa perusahaan relatif lebih stabil dan lebih mampu menghasilkan laba dibanding perusahaan dengan total asset yang kecil (Daniati dan Suhairi, 2006).

Aktiva merupakan tolak ukur besaran atau skala suatu perusahaan. Perusahaan yang besar akan cendrung lebih mudah dalam mengakses sumber pendanaan. Secara teoritis perusahaan yang lebih besar mempunyai kepastian (certainty) yang lebih besar daripada perusahaan yang kecil sehingga akan mengurangi tingkat ketidakpastian mengenai prospek perusahaan ke depan. Hal tersebut dapat membantu investor memprediksi risiko yang mungkin terjadi. Hasil penelitian $\mathrm{Pu}-$ tri, Sudarma dan Purnomosidhi (2016) menunjukkan bahwa ukuran perusahaan mampu memoderasi CSR terhadap nilai perusahaan. Ukuran perusahaan berpengaruh positif terhadap nilai perusahaan (Haryanto, 2014; Prasetyorini, 2013; Siahaan, 2013; Hasnawati dan Sawir, 2015).

$\mathrm{H}_{2}$ : Ukuran perusahaan berpengaruh terhadap nilai perusahaan.

\section{Kinerja Perusahaan dan Nilai Perusahaan}

Dalam analisis fundamental kinerja perusahaan merupakan fokus utama bagi investor. Kinerja perusahaan merupakan capaian manajemen dalam mengelola perusahaan. Semakin tinggi kinerja perusahaan mengindikasikan manajemen telah melakukan pengelolaan perusahaan dengan 
efisien. Dalam signaling theory manajemen akan menyampaikan kinerja perusahaan sebagai sinyal prospek perusahaan di masa depan. Perusahaan dengan kinerja yang tinggi menunjukkan perusahaan tersebut sehat dan memiliki prospek yang baik. Investasi pada perusahaan dengan kinerja yang baik akan mengurangi risiko yang dihadapi investor. Kinerja perusahaan yang tinggi merupakan sinyal positif bagi investor terhadap perusahaan tersebut. Sehigga harga saham perusahaan akan cenderung meningkat. Peningkatan harga saham menunjukkan nilai perusahaan juga meningkat. Hasil penelitian menunjukkan kinerja perusahaan berpengaruh positif terhadap nilai perusahaan. Penelitian Siregar, Roekhudin dan Purwanti (2018), Ananda (2018), Kurniawan (2018), Susanti\& Restiana (2018), Meythi (2013), Kellen (2011) menunjukkan kinerja perusahaan berpengruh positif terhadap nilai perusahaan. Penelitian Hidayah (2014)

$\mathrm{H}_{3}$ : Kinerja perusahaan berpengaruh terhadap nilai perusahaan.

\section{DATA DAN METODE}

Penelitian ini merupakan penelitian explanatory, dengan data sekunder. Populasi penelitian merupakan industri perbankan yang ada di Indonesia. Teknik sampling yang digunakan purposive sampling. Periode penelitian selama 4 tahun, yaitu tahun 2013-2016. Berdasarkan kriteria sampel diperoleh sampel penelitian sejumlah 27 bank, dengan periode pengamatan selama 4 tahun, maka diperoleh sebanyak 108 pasang data. Variabel nilai perusahaan digunakan price earning ratio (PER), struktur modal diukur dengan debt to equity ratio (DER), ukuran perusahaan diproksikan dengan logaritma natural (natural log) dari jumlah aset dan kinerja perusahaan digunakan ROA (return on asset). Sumber data penelitian merupakan data sekunder yang berasal dari Laporan keuangan masing-masing bank yang dipublikasikan oleh BEI. Teknik pengumpulan dilakukan dengan dokumentasi, dari laporan keuangan masing-masing perusahaan dan harga sahamnya. Teknik analisis data digunakan dalam penelitian ini adalah deskriptif kuantitatif, dengan menggunakan analisis analisis jalur atau struktur equation model dengan persamaan sebagi berikut:

$$
Y=\propto+\beta_{1} X_{1}+\beta_{2} X_{2}+\beta_{3} X_{3}+e
$$

Keterangan: $Y=$ Kinerja keuangan; $\alpha=$ Konstanta; $\mathrm{b}_{1-3}=$ Koefisien regresi; $\mathrm{X}_{1}=$ struktur modal; $\mathrm{X}_{2}=$ Ukuran Perusahaan; $X_{3}=$ Ukuran Perusahaan dan $\mathrm{e}=$ Disturbance error

\section{HASIL}

\section{Deskrispsi data}

Nilai perusahaan merupakan persepsi investor terhadap prospek suatu perusahaan. Nilai perusahaan yang diproksikan dengan Price Earning Ratio (PER). PER merupakan perbandingan antara EPS dengan harga saham. Semakin tinggi PER menunjukkan ekspektasi investor terhadap suatu perusahaan akan semakin tinggi. Hal ini karena harga saham di pasar yang semakin tinggi. Nilai PER rata-rata bank di Indonesia sebesar 12,63 dan tertinggi sebesar 48,190 dan terendah sebesar $-8,930$ (Tabel 1). Nilai PER negatif mengindikasikan perusahaan tersebut mengalami kerugian. PER pada industry perbankan cukup bervarian, hal ini dipengaruhi oleh kinerja bank yang juga cukup bervariasi dan asset bank yang juga sangat bervariasi.

Berdasarkan hasil analisis deskripsi data (Tabel 1) dari 27 bank dengan pengamatan selama tahun 2013-2016 menunjukkan rata-rata sebesar 7,96, dengan nilai tertinggi DER tertinggi sebesar 13,22 . Hutang merupakan salah satu sumber pembiayaan bank, selain dari sumber dana pihak pertama (modal), juga dari dana pihak ketiga (DPK). Hutang dalam struktur pendanaan bank memang tidak terlalu besar, karena bank sebagai lembaga intgermediasi maka sumber pembiayaan paling besar berasal dari DPK. Proporsi hutang dan modal (ekuitas) lebih cenderung untuk membiayai investasi jangka panjang bank. DER bank relatif yang kecil, mengindikasikan bahwa hutang cenderung hanya untuk menutup kebutuhan dana investasi jangka panjang suatu bank.

Aktiva perusahaan merupakan salah satu ukuran perusahaan. Semakin besar aktiva perusahaan menunnjukkan perusahaan tersebut semakin besar dan sebaliknya semakin kecil aktiva perusahaan akan semakin kecil perusahaan tersebut. Rata-rata aktiva bank sebesar Rp 148, 55 trilyun (Tabel 2). Dilihat dari ukuran bank, bank-bank di Indonesia menunjukkan sangat bervarian. Bankbank BUMN dan beberapa bank swasta memeilki asset yang besar, seperti Bank Mandiri, Bank BRI, Bank BNI serta Bank BTN dan BUSN yang termasuk besar adalah Bank BCA. Namun beberapa bank swasta nasional memiliki asset yang jauh lebih kecil.

ROA merupakan ukuran profitabilitas untuk bank. Semakin tingi ROA menunjukkan bank tersebut semakin efisien dalam mengelola sumber daya yang dimilkinya. Bank sebagai lembaga intermediasi, dimana aset bank yang sebagian besar 
Kebijakan Hutang, Ukuran Perusahaan dan Kinerja Keuangan Terhadap Nilai Perusahaan: Industri Perbankan di Indonesia

Sugeng Haryanto, Nabila Rahadian, Maria Fatima Ima Mbapa, Eka Nesty Rahayu, dan Khoiriyah Vivi Febriyanti,

dari dalam bentuk kredit. Dimana sumber dana kredit berasal dari DPK. Sehingga dengan menggunakan ROA akan dapat dilihat bagaimana suatu bank menjalankan fungsi intermediasinya untuk menghasilkan laba. Profitabilitas bank di Indonesia, rata-rata membukukan laba. Besarnya rata-rata ROA bank sebesar 1,384 \% (Tabel 1). Hal ini menunjukkan bahwa secara umum bank di Indonesia sehat. Karena mampu membukukan laba. Semakin tinggi ROA suatu bank, maka bank tersebut akan semakin sehat.

Tabel 1 Deskripsi data

\begin{tabular}{lllll}
\hline & DER & Ukper & ROA & PER \\
\hline Rata-rata & 7,96 & 148.550 .217 & 1,384 & 12,630 \\
Tertinggi & 13,22 & 855.039 .673 & 3,410 & 48,190 \\
Tertendah & 4,78 & 3.601 .336 & $-1,320$ & 8,930 \\
\hline
\end{tabular}

Berdasarkan hasil analisis menunjukkan bahwa struktur modal berpengaruh terhadap nilai perusahaan, dengan arah negatif (Tabel 2). Hal ini menunjukkan bahwa peningkatan struktur modal, yaitu dengan meningkatnya proporsi hutang dibandingkan modal akan cenderung direspon negatif oleh investor. Ukuran perusahaan tidak berpengaruh terhadap nilai perusahaan. Hal ini menunjukkan bahwa investor cenderung dalam menanamankan dananya tidak melihat besar kecilnya perusahaan sebagai pertimbangan penting. Selanjutnya kinerja perusahaan berpengaruh terhadap nilai perusahaan dengan arah positif. Hal ini menunjukkan bahwa kinerja perusahaan yang semakin baik, merupakan positif bagi investor terhadap prospek perusahaan tersebut.

Tabel 2. Hasil Analisis Regresi

\begin{tabular}{llll}
\hline Variabel & Coefficients & & t Probabilitas \\
\hline Constant & 67,086 & 3,294 & 0,002 \\
DER & $-1,847$ & $-2,509$ & 0,015 \\
Ukper & $-578,57$ & $-1,949$ & 0,057 \\
ROA & 5,047 & 2,904 & 0,005 \\
\hline $\mathrm{R}^{2}$ & $: 0,171$ & & \\
$\mathrm{R}^{2}$ Adj & $: 0,121$ & & \\
$\mathrm{~F}_{\text {Hitung }}$ & $: 3,433$ & & \\
$\mathrm{~F}_{\text {Sig }}$ & $: 0,024$ & & \\
DW & $: 2,410$ & & \\
\hline
\end{tabular}

\section{PEMBAHASAN}

\section{Pengaruh Kebijakan Hutang Terhadap Nilai Perusahaan}

Berdasarkan hasil analisis seperti disajikan pada Tabel 2 menunjukkan bahwa kebijakan hutang berpengaruh terhadap nilai perusahaan dengan arah negatif. Kebijakan hutang diproksikan dengan DER. Hasil ini menunjukkan bahwa peningkatkan hutang bank, yang tercermin dari peningkatan nisbah hutang dengan modal yang semakin tinggi akan cenderung direspon negatif oleh investor. Hutang bank cenderung digunakan untuk membiayai investasi-investasi jangka panjang (aktiva tetap). Investor cenderung akan merespon bank-bank dengan hutang yang semakin besar, menunjukkan kemampuan permodalan bank untuk membiayai investasi jangka panjang terbatas. Sehingga investor akan cenderung merespon negatif, dengan peningkatan hutang bank tersebut.

Hutang bank yang semakin besar, akan berimplikasi pada risiko yang dihadapi bank juga akan semakin tinggi. Perusahaan dengan hutang yang semakin besar, maka risiko dan beban yang ditanggung perusahaan akan semakin besar. Perusahaan akan menanggung beban angsuran dan bunga yang tinggi seiring dengan meningkatnya hutang, walaupun perusahaan tersebut mengalami kerugian. Peningkatan hutang disatu sisi akan menurunkan pajak, namun disisi lain akan cenderung meningkatkan biaya yang harus dikeluarkan perusahaan untuik membayar bunga, sehingga dapat mengurangi laba bersih perusahaan. Temuan penelitian ini sejalan dengan temuan penelitian Antwi, Mills dan Zhao (2012), Ogbolu dan Emeni (2012) dimana peningkatkan hutang jangka panjang justru akan berpengaruh negatif terhadap nilai perusahaan. Namun penelitian ini tidak sejalan dengan temuan penelitian yang dilakukan oleh Chowdhury dan Chowdhury (2010); Artini dan Puspaningsih (2011); Kodongo, Mokoteli dan Maina (2014), Sulistiono (2016).

\section{Pengaruh Ukuran Perusahaan Terhadap Nilai Perusahaan}

Berdasarkan hasil analisis regresi menunjukkan ukuran perusahaan tidak berpengaruh terhadap nilai perusahaan. Ukuran perusahaan diukur dengan nilai logaritma dari total aktiva. Hal ini menunjukkan bahwa besar kecilnya perusahaan tidak berpengaruh pada ekspektasi investor yang tercermin dari nilai perusahaan. Bank yang besar, maka biaya yang harus dikeluarkan juga cenderung besar. Bank harus membiayai SDM dan assetasetnya yang juga cukup besar. Selain itu bank yang besar terkadang kurang fleksibel beradaptasi terhadap perubahan lingkungan bisnis.

Bagi investor besar kecilnya suatu bank kurang menjadi perhatian. Bank yang besar belum tentu menjamin bank tersebut memiliki prospek yang baik dan sebaliknya bank yang kecil belum 
tentu prospeknya kurang baik. Bank yang besar cenderung merupakan bank yang sudah berumur lama. Dalam kondisi lingkungan bisnis yang terbuka, global dan dapat berubah dengan cepat, maka tidak menjamin bank yang besar mampu beradaptasi dengan cepat. Seringkali bank besar justru lebih sulit untuk melakukan perubahan. Padahal dalam kondisi ekonomi yang global diperlukan kecepatan perusahaan untuk beradaptasi dengan cepat terhadap perubahan lingkungan bisnis. Hasil penelitian ini tidak sejalan dengan temuan penelitian Lin, 2006; Wright dan Ferris, 1997 dan Calisir et al., 2010; Utomo, 2016; Pasaribu dan Tobing , 2017). Sedangkan temuan Susanti dan Restiana (2018) menunjukkan bahwa ukuran perusahaan berdampak negative terhadp nilai perusahaan.

\section{Pengaruh Kinerja Keuangan Terhadap Nilai Perusahaan}

Berdasarkan hasil penelitian menunjukkan bahwa kinerja keuangan berpengaruh nilai perusahaan, dengan arah positif. Hasil ini mengindikasikan bahwa kinerja perusahaan yang meningkat akan cenderung direspon positif oleh investor. Kinerja perusahaan merupakan salah satu ukuran untuk melihat bagaimana prospek perusahaan. Semakin baik kinerja keuangan perusahaan, maka akan semakin baik pula prospek perusahaan. Perusahaan dengan prospek yang semakin baik tentunya akan lebih menarik investor untuk menanamkan dananya di perusahaan tersebut. Perusahaan dengan kinerja yang baik, akan menarik investor untuk membeli sahamnya. Ketika permintaan saham suatu perusahaan meningkat, maka akan mendorong harga saham perusahaan tersebut akan meningkat pula, sehingga nilai perusahaan akan meningkat.

Bank dengan kinerja yang meningkat menunjukkan bank tersebut sehat. Investor akan cenderung menginvestaikan dananya pada perusahaan dengan tingkat risiko yang rendah. Investasi pada bank yang sehat, akan cenderung risikonya lebih rendah. Sehingga bank dengan kinerja yang meningkat, merupakan sinyal positif bagi investor. Hasil penelitian ini mendukung temuan penelitian Siregar, Roekhudin dan Purwanti (2018), Ananda (2018), Kurniawan (2018), Kusna dan Setijani (2018), Ariyani, Mintarti dan Kusumawardani (2018), Purwohandoko (2017), Andawasatya, Indrawati2 \& Aisjah (2017), Mulyawati, Lestari \& Nurleli (2015), Meythi (2013), Ayuningtias (2013), Kellen (2011), dan Haryanto (2011) menunjukkan kinerja perusahaan berpengaruh positif terhadap nilai perusahaan. Namun temuan penelitian ini tidak sesuai dengan temuan penelitian Sutrisno (2016) dimana laba perusahaan tidak berpengaruh terhadap nilai perusahaan.

\section{SIMPULAN DAN SARAN}

Berdasarkn hasil analisis dan pembahasan penelitian menunjukkan bahwa struktur modal berpengaruh terhadap niali perusahaan dengan arah negatif. Ukuran perusahaan tidak berpengaruh terhadap nilai perusahaan. Kinerja perusahaan berpengaruh positif terhadap nilai perusahaan. Bank dengan kinerja yang baik akan memiliki prospek, sehingga risikonya akan lebih rendah. Investor akan cenderung menanamkan dananya pada perusahaan yang cenderung memiliki prospek yang baik dan risiko yang rendah. Bank dengan hutang jangka panjang yang besar, sehingga struktur modalnya meningkat cenderung akan memiliki risiko yang lebih tinggi. Investor cenderung merespon bank dengan hutang yang besar sebagai sesuai yang kurang baik.

Penelitian ini dilakukan terbatas pada industry perbankan, dengan waktu selama 4 tahun. Variabel yang digunakan juga masih terbatas, yaitu hanya struktur modal, ukuran perusahaan dan kinerja perusahaan sebagai prediktor nilai perusahaan. Untuk penelitian selanjutnya dapat dilakukan dengan menambah periode penelitian serta dapat dikelompokkan antara bank-bank besar, menengah dan kecil. Periode waktu yang panjang akan dapat dilihat stabilitas bank-bank yang menjadi objek penelitian. Variabel penelitian dapat ditambahkan dengan stabilitas bank, diversifikasi pendapatan bank.

\section{DAFTAR PUSTAKA}

Ananda, F. A., (2018). Struktur Modal, Kinerja Perusahaan dan Altman Z-Score Pengaruhnya Terhadap Ekspektasi Investor. Accounting and Financial Review. 1(1): 9-16

Andawasatya R.R., Nur Khusniyah Indrawati, N.K. \& Siti Aisjah, S. (2017). The Effect of Growth Opportunity, Profitability, Firm Size to Firm Value through Capital Structure (Study at Manufacturing Companies Listed On the Indonesian Stock Exchange). Imperial Journal of Interdisciplinary Research (IJIR). 3(2)

Andrade, G. Kaplan, S.N. (1998). How Costly is Financial (not Economic) Distress? Evidence from Highly Leveraged Transactions that Became Distressed. Journal of Finance. 53: 
Kebijakan Hutang, Ukuran Perusahaan dan Kinerja Keuangan Terhadap Nilai Perusahaan: Industri Perbankan di Indonesia

Sugeng Haryanto, Nabila Rahadian, Maria Fatima Ima Mbapa, Eka Nesty Rahayu, dan Khoiriyah Vivi Febriyanti,

1443-1493.

Antwi, S., Mills, E.F.E.A. and Zhao, X. (2012). Capital Structure and Firm Value: Empirical Evidence from Ghana. International Journal of Business and Social Science. 3(22)

Arief Yulianto, A. (2013). Keputusan Struktur Modal dan Kebijakan Dividen Sebagai Mekanisme Mengurangi Masalah Keagenen. JDM Jurnal Dinamika Manajemen. 4(2): 161179.

Ariyani, Y., Mintarti, S., dan Kusumawardani, A. (2018). Analisis Pengaruh Profitabilitas, Solvabilitas dan Likuiditas Terhadap Nilai Perusahaan Pada Perusahaan transportasi yang Terdaftar di bursa efek Indonesia. Jurnal Ilmu Akuntansi. 3(2).

Artini, L.G.S. dan Puspaningsih, N.L.A. (2011). Struktur Kepemilikan dan Struktur Modal terhadap Kebijakan Dividend dan Nilai Perusahaan. Jurnal Keuangan dan Perbankan. 15(1): 66-75.

Ayuningtias, D. (2013). Pengaruh Profitabilitas Terhadap Nilai Perusahaan: Kebijakan Dividend Dan Kesempatan Investasi Sebagai Variabel Antara. Jurnal Ilmu dan Riset Akuntansi. 1(1)

Brigitta Clarabella Petta, B.C. dan Josua Tarigan, J. (2017) Pengaruh Kepemilikan Institusional Terhadap Kinerja Keuangan Melalui Struktur Modal Sebagai Variabel Intervening Pada Perusahaan Manufaktur Yang Terdaftar Dalam Burs Efek Indonesia (BEI). Business Accounting Review. 5(2): 625-636

Calisir, F.,Gumussoy,C.A.,Bayraktaroglu, A.E.and Deniz, E. (2010). Intellectual capital in the quoted Turkish ITC sector. Journal of Intellectual Capital. 11(4): 537-553.

Chadha, S and Sharma, K.A.,(2015). Capital Structure and Firm Performance: Empirical Evidence from India. Vision: The Journal of Business Perspective. 19(4): 295-302.

Chandrarin, G. dan Cahyaningsih, S.D. (2018). Identifikasi Struktur Modal Melalui Profitabilitas, Pertumbuhan Penjualan, dan Ukuran Perusahaan. Accounting and Financial Review, 1(1)

Chowdhury, A and Chowdhury, S.P. (2010). Impact of Capital Structure on Firm's Value: Evidence from Bangladesh. BEH-Business and
Economic Horizons. 3(3): 111-122.

Cuong, T.N. and Canh, N.T. (2012). The Effect of Capital Structure on Firm Value for Vietnam's Seafood Processing Enterprises. International Research Journal of Finance and Economics Issue. (89): 221-223.

Daniati, N. dan Suhairi. (2006). Pengaruh Kandungan Informasi Komponen Arus Kas, Laba Kotor dan Size Perusahaan Terhadap Expected Return Saham Pada Industri Textile dan Automotive yang Terdaftar di BEJ. Simposium Nasional Akuntansi 9 Padang, Agustus.

Detthamrong, U., Chancharat, N., and Vithessonthi, C. (2017). Corporate governance, capital structure and firm performance: Evidence from Thailand. Research in International Business and Finance. 42, December: 689-709

Haryanto, S. (2014). Identifikasi Investor Melalui Kebijakan Struktur Modal, Profitabilitas, Ukuran Perusahaan dan GCPI. JDM Jurnal Dinamika Manajemen. 5(2): 183-199

Haryanto, S. (2011).Karakteristik Perusahaan dan Risiko Bisnis Terhadap Harga Saham Pada Industri Otomotif di Bursa Efek Indone sia. Jurnal Ekonomi Modernisasi. 7(2)

Hasnawati, S dan Sawir, A. (2015). Keputusan Keuangan, Ukuran Perusahaan, Struktur Kepemilikan dan Nilai Perusahaan Publik Di Indonesia. Jurnal Manajemen dan Kewirausahaan. 17(1): 65-75.

Hermuningsih, S. (2013). Profitability, Growth Opportunity, Capital Structure and The Firm Value. Bulletin of Monetary, Economics and Banking. October.

Hidayah, N. (2014). The effect of company characteristic toward company value in the property and real estate company in Indonesia Stock Exchange. International Journal of Business, Economics, and Law. 5(1): 1-8.

Jensen and Meckling. (1976). Theory Of The Firm: Manajerial Behavior, Agency Cost And Ownership Structure. Journal of Financial Economics. 3

Kellen, P.B. (2011). Struktur Kepemilikan, Profitabilitas dan Risiko Perusahaan Terhadap Struktur Modal dan Nilai Perusahaan. Jurnal Keuangan dan Perbankan. 15(1): 201-212.

Kodongo, O., Mokoaleli, T. and Maina, L. (2014). 
Capital Structure, Profitability and Frm Value: panel evidence of listed firms in Kenya. MPRA Paper No. 57116.

Kusna, I dan Setijani, E. (2018). Analisis Pengaruh Kinerja Keuangan, Growth Opportunity Dan Ukuran Perusahaan Terhadap Struktur Modal Dan Nilai Perusahaan. JMDK Jurnal Manajemen dan Kewirausahaan. 6(1): 93-102

Kurniawan, Y.M., (2018). Indonesia Most Trusted Company dan Nilai Perusahaan. Accounting and Financial Review. 1(1): 1-8

Lin, K. L. (2006). Study on Related Party Transaction with Mainland China in Taiwan Enterprises. Unpublished Dissertation. China: Departemen Manajemen, Universitas Guo Li Cheng Gong.

Meythi. (2013). Rasio Keuangan Terbaik Untuk Memprediksi Nilai Perusahaan. Jurnal Keuangan dan Perbankan. 17(2): 200-210

Mulyawati, S., Lestari, R., \& Nurleli, N. (2015). Pengaruh kinerja keuangan terhadap nilai perusahaan. Proceedings of Accounting UNISBA, 180-189

Myers, S.C and Majluf, N.S. (1984). Corporate Financing and Investment Decisions When Firms Have Information That Investors Do Not Have. Journal of Financial Economics 13: 87-221.

Ogbulu, O.M and Emeni, F.K. (2012). Capital Structure and Firm Value: Empirical Evidence from Nigeria. International Journal of Business and Social Science. 3(19): 252-261

Pasaribu, D dan Tobing, D.L.L. (2017). Analisis Pengaruh Struktur Modal, Profitabilitas, Kebijakan Dividend an Ukuran Perusahaan TErhadap Nilai Perusahaan Pada Perusahaan Farmasi yang Terdaftar Di Bursa Efek Indonesia. Jurnal akuntansi dan Keuangan Methodist. 1(1)

Prasetyorini, B. F. (2013). Pengaruh Ukuran Perusahaan, Leverage, Price Earning Ratio dan Profitabilitas terhadap Nilai Perusahaan. Jurnal Ilmu Manajemen. 1(1): 183-196.

Purwohandoko. (2017). The influence of firm's size, growth, and profitability on firm value with capital structure as the mediator: A study on the agricultural firm listed in Indonesia Stock Exchange. International Journal of Economic and Finance, 9(8): 103-110.
Putri, A.K., Sudarma, Made dan Purnomosidhi, B. (2016). Pengaruh Corporate Social Responsibility terhadap Nilai Perusahaan dengan Ukuran Perusahaan dan Jumlah Dewan Komisaris sebagai Variabel Pemoderasi (Studi pada Perusahaan Manufaktur yang terdaftar Bursa Efek Indonesia). Jurnal Aplikasi Manajemen. 14(2): 344-358.

Siahaan, O.P.F. (2013). The Effect of Good Corporate Governance Mechanism, Leverage, and Firm Size on Firm Value. GSTF Journal on Business Review (GBR). 2(4).

Siregar, I.F., Roekhudin dan Purwanti, L. (2018). Firm Value Predictor and the Role of Corporate Social Responsibility. Jurnal Keuangan dan Perbankan. 22(3): 475-485.

Subagyo, H. (2011). Efektivitas Kebijakan Struktur Modal Dalam Meningkatkan Nilai perusahaan. Jurnal Bisnis dan Ekonomi (JBE). 18(1): 59-68.

Sulistiono, S. (2016). Pengaruh Struktur Modal, Kebijakan Dividen dan Investment Opportunity Set terhadap Nilai Perusahaan (Studi pada Perusahaan-perusahaan Manufaktur di PT. Bursa Efek Indonesia). 7 th Industrial Research, Workshop, and National Seminar. Politeknik Negeri Bandung, July 28 - 29.

Susanti, N., \& Restiana, N. G. (2018). What's the best factor to determining firm value? Jurnal Keuangan dan Perbankan. 22(2), 301-309. https:// doi.org/10.26905/jkdp.v22i2.1529

Suteja, J. dan Ginting, G. (2014). Determinan Profitabilitas Bank: Suatu Studi pada Bank yang Terdaftar di BEI. Trikonomika. 13(1): 62-77.

Sutrisno. (2016). Capital structure determinants and theirimpact on firm value: Evidence from Indonesia. Economics. 4(4).

Utomo, N.A., (2015). Faktor-Faktor yang Mempengaruhi Nilai Perusahaan PAda Perusahaan Indeks LQ45 di Bursa Efke Indonesia. Dinamika Akuntansi, Keuangan dan Perbankan. 5(1)

Vavatu, S. (2015). The impact of capital structure on financial performance in Romanian listed companies. Procedia Economics and Finance. 32: 1314-1322

Vo, V.X., and Ellis, C. (2017). Empirical Investigation of Capital Structure and Firm Value in Vietnam. Finance Research Letters. Agustus. 
Kebijakan Hutang, Ukuran Perusahaan dan Kinerja Keuangan Terhadap Nilai Perusahaan: Industri Perbankan di Indonesia

Sugeng Haryanto, Nabila Rahadian, Maria Fatima Ima Mbapa, Eka Nesty Rahayu, dan Khoiriyah Vivi Febriyanti,

22: 90-94.

Yulianto, A. (2013). Keputusan Struktur Modal dan Kebijakan Dividen Sebagai Mekanisme Mengurangi Masalah Keagenen. JDM Jurnal Dinamika Manajemen. 4(2): 161-179.

Zichao, J., Lu, D and Ruiyang, Xu (2018). How Does Debt Structure Influence Stock Price Crash Risk?. J Syst Sci Complex. 31: 473-492.

Wright, P. and Feriis, S. (1997). Agency Conflict and Corporate Strategy: The Effect of Divesment on Corporate Value. Strategic Management. 18(1). 